\title{
Scholarly Communication and the Dilemma of Collective Action: Why Academic Journals Cost Too Much
}

\author{
John Wenzler
}

\begin{abstract}
Why has the rise of the Internet-which drastically reduces the cost of distributing information-coincided with drastic increases in the prices that academic libraries pay for access to scholarly journals? This study argues that libraries are trapped in a collective action dilemma as defined by economist Mancur Olson in The Logic of Collective Action: Public Goods and the Theory of Groups. To truly reduce their costs, librarians would have to build a shared online collection of scholarly resources jointly managed by the academic community as a whole, but individual academic institutions lack the private incentives necessary to invest in a shared collection. Thus, the management of online scholarly journals has been largely outsourced to publishers who have developed monopoly powers that allow them to increase subscription prices faster than the rate of inflation. Many librarians consider the open access movement the best response to increased subscription costs, but the current strategies employed to achieve open access also are undermined by collective action dilemmas. In conclusion, some alternative strategies are proposed.
\end{abstract}

\section{Electronic Resources and Collective Action}

During the 20th century, the network of college and university libraries in the United States provided the most efficient means of sharing the results of scholarly activity published in academic journals. Some 1,000 to 2,000 copies of a printed journal article housed on library shelves scattered around the country offered relatively convenient access to most interested readers, and long-term preservation was ensured by having so many copies stored in institutional environments managed by professionals. In the 21st century, however, digital networks have given us a more efficient method of sharing scholarly ideas. One electronic copy of an article housed on an Internet server provides researchers much better access than did 2,000 printed copies housed in the stacks. Today, a scholar associated with a research institution can discover and read any digital article available through her library subscriptions almost immediately without the time and effort required to visit the library building and locate it on the shelves. For long-term preservation, one digital copy of an article is not enough, but

John Wenzler is Dean of Libraries at California State University, East Bay; e-mail: john.wenzler@csueastbay. edu. (02017 John Wenzler, Attribution-NonCommercial (http://creativecommons.org/licenses/by-nc/4.0/) CC BY-NC. 
3-5 copies housed on geographically dispersed servers in data centers with robust disaster recovery protocols should be sufficient.

The new technology for sharing scholarly articles offers tremendous potential savings to academic libraries. The collective cost of managing journal collections can be greatly reduced by eliminating the expenses of printing, binding, shipping, labeling, shelving, tracking, reshelving, and storing paper. Researchers have estimated that the "costs of constructing and maintaining the space required to keep a 2,500-page journal volume permanently on accessible library shelves is roughly $\$ 1,000 .{ }^{11}$ When multiplied by tens of thousands of journals published each year for scholars at thousands of institutions, the potential savings are significant. Born-digital journals never have to go on the shelves at all, and it is becoming unnecessary to maintain redundant copies of printed journals on library shelves as back issues are digitized.

Unfortunately, academic libraries so far have failed to benefit from the savings made possible by digital technology. Instead of enjoying new discretionary funds liberated by the transition to electronic collections, librarians still worry about the cost of their subscriptions. Journal prices continue to rise faster than the rate of inflation and absorb an increasing percentage of academic library budgets. ${ }^{2}$ Even Harvard Library, the wealthiest university library in the United States with an annual budget of over $\$ 123$ million, complains that journal prices are "fiscally unsustainable" and "academically restrictive." 3 How is it possible that a technological revolution that drastically reduces the overall costs of sharing scholarly information has coincided with fiscally unsustainable price increases for academic libraries and increasing anxiety about their ability to provide researchers with access to the resources that they need?

The fundamental hurdle that prevents academic libraries from enjoying the full economic benefits enabled by digital technology is the challenge of collaborating across traditional institutional boundaries. Network technology promises to reduce costs primarily by eliminating the need to build duplicate collections of redundant materials at hundreds of different locations. To realize this promise, academic librarians would have to transform their collections from a private good managed separately at each local institution into a public good shared by the academic community as a whole. A recent study by two OCLC researchers highlights the underlying shift in perspective and social organization that would be required:

While the invisible hand has worked quite well as a means of distributing and coordinating stewardship responsibilities attached to a largely print scholarly record, its effectiveness is diminishing in an era where the scholarly record is evolving into a digital, networked form. As a result, conscious coordination is likely to replace the invisible hand as the key principle underpinning stewardship models for the scholarly record, with local decisions taken in the context of broader system-wide conditions. ${ }^{4}$

In the print era, each library could focus on building its own collections while allowing the invisible hand of market exchange to distribute scholarly resources to the rest of the academic community. In the digital era, efficient management of online scholarly resources requires that libraries treat them as a "collective collection" shared by everyone. ${ }^{5}$

Although OCLC optimistically predicts that "conscious coordination is likely to replace the invisible hand," economists and political scientists long have argued that it is extremely difficult to replace the unconscious coordination made possible by market transactions with the conscious coordination required for collective action. Even when everyone involved understands and desires the benefits of cooperation, it is often impossible for them to work together to achieve it. Economist Mancur Olson's 
influential Logic of Collective Action: Public Goods and the Theory of Groups developed a thorough analysis of this dilemma in 1965. Olson argued that "even if all of the individuals in a large group are rational and self-interested, and would gain if, as a group, they acted to achieve their common interest or objective, they will still not voluntarily act to achieve that common or group interest." 6 Because everyone benefits from the creation of public good regardless of whether or not they help to produce it, individuals are tempted to become "free riders" who exploit the efforts of others. Even those who have no intention of free-riding for themselves are reluctant to invest in a public good because they worry that their effort will be wasted if too many other people chose to ride for free. In small communities, it often is possible to build bonds of reciprocal trust that allow groups to achieve collective ends, but it is more challenging for larger and more distributed groups to do so. ${ }^{7}$

Olson's thesis has broad implications and can be used to analyze many of the challenges faced by large groups in a modern economy. For example, individual employees negotiating their wages with large employers confront a collective action dilemma. Even if all of the employees of a company have full knowledge of its finances and know that it could easily pay everyone $\$ 20$ an hour, it still is difficult for them to achieve that wage if each employee has to negotiate separately with the company. An individual employee can safely refuse to work for less than \$20 if she knows that everyone else will do the same, but - if she fears that some of her colleagues will accept a lower wage-she may not get a job at all without making similar compromises. Workers' unions try to overcome this problem by negotiating collectively for employees, but-even when unions exist-employees still have an incentive to ride for free on the dues paid by others. Thus, Olson argued that "closed shops" are essential to the success of large unions: "over 90 per cent will not attend meetings or participate in union affairs; yet over 90 per cent will vote to force themselves to belong to the union and make considerable dues payments to it." ${ }^{8}$ The workers understand that voting to constrain their personal economic freedom benefits them as long as everyone in their industry faces the same constraints. The shared limitations on their personal freedom of choice allow them to achieve the larger benefits made possible through collective action. ${ }^{9}$

An historical example of a collective action dilemma - the challenges and opportunities faced by 19th-century American farmers after the invention of the railroad-sheds light on the current dilemma for academic libraries. Before railroads, farms far from rivers or urban centers were not profitable regardless of the productivity of their fields. The longer it took for a farmer to ship her products to the market, the less income she earned on her produce. Railroads greatly enhanced the value of outlying farms by drastically reducing transportation costs. But a farmer couldn't buy or build a railroad just for her own farm in the same way that she could buy new seeds or build new fences. It would have made no sense to build isolated tracks across her own land. To be useful, railroad tracks have to be connected to a larger network, and a railroad line becomes a public good shared by all of the producers who use it to ship their products to market. In theory, it would have been possible for a group of farmers in a region to build a shared railroad line for themselves. Collectively, the investment that they would have had to make to build a connection to the closest urban hub easily would have been paid for by the increased income on their farms. Despite the great potential benefits of cooperation, however, railroad lines were never built by collaborative groups of farmers in the United States. The challenges of coordinating investments for large groups scattered across the landscape would have been too difficult to overcome.

Academic librarians face similar challenges in building a shared infrastructure for scholarly communication. In theory, it is easy to imagine that academic libraries could build a shared digital collection that would benefit the entire academic community at 
relatively low costs. Currently, the Internet Archive charges $\$ 0.10$ a page and $\$ 3.00$ per volume to digitize and store books in its online archive. ${ }^{10}$ For a 50-volume, 2,500-page journal, the cost of digitization with the Internet Archive would be $\$ 370$, less than half the estimated $\$ 1,000$ cost of storing the printed version of the journal in a single academic library. ${ }^{11}$ Assuming that the prices charged by the Internet Archive roughly cover its costs, it should be possible for a large group of libraries working together to digitize and share print journal collections duplicated at hundreds of different institutions at a fraction of the cost that they currently spend to maintain so many redundant copies on their shelves. Born-digital journal issues could be added to the collection at even lower costs. But how would libraries develop the relationships and institutions required to achieve this shared collection? Although a single shared digital collection would be cheaper to maintain than many redundant print collections, there still would be costs. Who would pay for them? Which institutions would build and maintain the shared library? Who would control access to it and maintain copyright restrictions? How would the builders be compensated by other institutions that use the library? Who would make the decisions about what to include and exclude or how the discovery interface should function? These questions underline challenges of conscious coordination confronted by academic libraries in the digital era. ${ }^{12}$

\section{Outsourcing and Monopoly}

For 19th-century farmers, the problem of building railroads was resolved by outsourcing the task to private corporations. The U.S. railroad system was built by private companies, often with the assistance of large government subsidies and land grants designed to stimulate private investment in a collective good. ${ }^{13}$ This approach avoided problems of collective action because a single economic organization made all of the investments and collected all of the profits without having to worry about free riders. Unfortunately for farmers, privatizing a collective good often limits the economic benefits that nonowners derive from it. Although the rapid expansion of the railroad network in the 19th century contributed to tremendous economic growth, railroad corporations often monopolized the increased profits made possible by using their network. After a railroad is built close to her farm, a farmer may be able to charge twice as much for her crops by shipping them rapidly to the city, but if there is only one railroad available to her - and there often was because it was so expensive to build redundant tracks - the railroad corporation can force her to pay them almost all of her increased income for the privilege of using their trains. Her only alternative is not to use the railroad at all and go back to the reduced level of income available to her before the tracks were built. By the 1870s, many farmers had come to see railroad corporations not as benefactors who stimulated economic development but as monopolistic "octopi" that undermined their rightful prosperity. ${ }^{14}$

The relationship between academic libraries and academic publishing corporations in the 21st century increasingly mirrors the relationship between farmers and railroad corporations in the 19th century. Throughout the 20th century, universities outsourced some of the costs of scholarly communication to publishers. A specialized scholarly journal usually has a small audience distributed across many institutions with no one university housing more than a minority of the readers interested in a particular publication. For a single university, it makes little economic sense to internalize the costs of editing, printing, and managing peer review for a journal that might be read by five people on campus. Much better to outsource those costs to a publisher who can recover the costs of publication through the marketplace. Although some academic publishers are subsidized by the university as university presses, the bulk of their costs also are covered by market transactions with customers outside the institution. Un- 
like publishers, libraries have traditionally focused on local, internal costs that would have been difficult to fund through market transactions with external customers. After purchasing the printed product, libraries store and organize their collections and make them available at no charge to members of their institution. ${ }^{15}$

With the growth of digital networks, the traditional boundaries between the internal institutional costs and the broader community-wide costs of scholarly communication have shifted. Now that it is possible to organize, store, and track scholarly publications on the network, publishers can take these tasks away from libraries. After producing the digital first copy of an article, it is easier for the publisher to host the article on its own servers and charge subscribers for access than it would be for the publisher to send digital copies out to a thousand different libraries for them to manage. In an economic sense, libraries continue to focus on the internal costs borne by local institutions while publishers continue to serve the needs of a broader audience through market transactions, but the new technology has contracted the scope of the academic libraries' local responsibilities for managing collections while expanding the systemwide tasks outsourced to publishers. ${ }^{16}$

At the same time, a few of the largest publishers have developed increasing market power. Journal publishers always have had monopolistic control over the specific articles in their journals because academic authors usually transfer copyright to them. A library may find similar journal titles on similar topics from other publishers, but they cannot get exactly the same content from anyone else. Especially for prestigious journals, "a company [that] owns the must-read title in, say, vibrational spectroscopy ... has a nice little captive market." ${ }^{\prime 17}$ Because researchers and librarians are not likely to consider any of the alternatives acceptable, publishers have some power to raise prices without worrying about cancellations. In the late 20th century, the limited monopoly powers previously enjoyed by a large number of relatively small publishers increasingly concentrated in the hands of a few powerful corporations that absorbed many of their competitors. In the 1990s, librarians often discussed the "serials crisis" caused by the increased volume of scholarly output and the rapidly increasing prices charged by large for-profit academic publishers, especially in the sciences. ${ }^{18}$

In the 21st century, the economies of scale made possible by the digital economy have further enhanced the market power of the largest publishers. According to a recent analysis, the top five academic publishers (Elsevier, Wiley, Sage, Springer, Taylor \& Francis) accounted "for more than $50 \%$ of all papers published in 2013."19 As the dominant publishers build databases, discovery systems, and online platforms to house large and integrated collections of journals, it is more difficult for small publishers to compete with them. Building an effective platform for publishing e-journals is expensive. Elsevier reported that they invested $\$ 360$ million to develop their ScienceDirect platform and spend about half that each year on maintenance and development. ${ }^{20}$ After a platform has been created, it is much cheaper and easier to add new journals to it than to build new and redundant platforms.

Centralized digital control allows the dominant academic publishers to use bundling and price discrimination to maximize their profits. ${ }^{21}$ Without the necessity of printing physical copies, the cost of providing access to one customer is essentially the same as providing access to 1,000 or more customers. Similarly, the cost of giving a customer access to a single journal on a publisher's platform is essentially the same as giving the customer access to the publisher's entire catalog of hundreds or thousands of journals. In this environment, the price that libraries pay is almost totally divorced from the costs of production and becomes a matter of negotiation. Publishers can bundle their journals together in "big deals" that give customers access to their entire catalog, and can charge higher prices to better-funded institutions. Currently, institutions granting 
master's degrees pay less than $\$ 100,000$ a year on average to access the same collection of Elsevier journals that cost most Research 1 institutions over $\$ 1$ million per year. ${ }^{22}$ In many ways, publisher consolidation, bundling, and price discrimination have been beneficial to researchers, especially at smaller institutions, who now have access to far more scholarly content than they ever had on the shelves of their library. ${ }^{23}$ But these practices give publishers pricing flexibility that allows them to try to charge the highest price that each institution is willing to pay and make it hard for new publishers to compete. If libraries try to shift some of their expenditures away from their big deals to other vendors, they risk losing access to all of the big publisher's journals.

As a result of the dominant publishers' market power, the cost of journal subscriptions has been rising faster than inflation, and large publishers enjoy high profit margins. The marketing firm Outsell estimates that the average profits for the academic journal publishing industry are 20 to 30 percent. For Elsevier, the profits may be as high as 40 to 50 percent, much higher than one would expect if they faced effective competition. ${ }^{24}$ Andrew Odlyzko, a mathematician at the University of Minnesota who has written extensively on scholarly electronic journals, argues that publishers have achieved higher profits primarily by appropriating a larger proportion of library budgets. Using ARL statistics, Odlyzko demonstrates that research libraries spent less than 20 percent of their budget on subscriptions in 1990 but were spending more than 27 percent on subscriptions by 2010 while spending on other library materials remained at the same level. ${ }^{25}$ Thus, less of the library's resources are going to staff, space, or other initiatives because more of its funding is going directly to the publishers. Just as 19th-century railroad corporations monopolized the profits made possible by railroad networks while farmers were left treading water, large publishers are monopolizing the cost savings made possible by digital networks while academic libraries struggle to stay afloat.

Unfortunately for librarians, it may be difficult to convince researchers who use their collections to share their sense of alarm about journal costs. In the analogy between railroad corporations and scholarly publishers, researchers at 21st-century American universities are in a position similar to 19th-century urban dwellers. Many people living in 19th-century American cities may have sympathized with the plight of the farmers and were morally opposed to the excess profits enjoyed by railroad corporations, but they themselves were benefitting from access to a more diverse and reliable food supply than most nonaristocrats had ever enjoyed in the past. Similarly, scholars in 21st-century universities may sympathize with librarians' complaints about journal costs and may express moral dismay at the excess profits that publishers derive from their academic labor, but they also enjoy much faster and more convenient access to a wider variety of scholarly content than any researcher has ever enjoyed in the past. ${ }^{26}$ At no cost to herself, a researcher affiliated with an American university usually can get immediate access to any article that she needs through library license agreements or occasionally through interlibrary loan with a slight delay. Even if researchers understand that the monopoly rents earned by publishers represent an unnecessary cost to the academic system as a whole, the costs do not have an immediate impact on their work because they are taken primarily from library budgets. As Odlyzko shows, ARL libraries have received a consistently declining percentage of overall university budgets in the last 20 years at the same time that journal subscription costs have drastically increased. ${ }^{27}$ From the perspective of university stakeholders outside of the library, the library's slice of the budget pie has been decreasing, and there is little sense that increasing journal prices adversely affect university initiatives outside of the library. 


\section{Open Access}

In response to concerns about journal costs, many librarians have enthusiastically embraced the open access (OA) movement, which seeks "world-wide electronic distribution of the peer-reviewed journal literature and completely free and unrestricted access to it by all scientists, scholars, teachers, students, and other curious minds." ${ }^{28}$ OA seeks to give people who are not affiliated with research institutions that have subscriptions to high-cost journals direct access to scholarly articles. In the past, the cost of distributing paper copies to this broader audience would have been prohibitively expensive, but giving access to everyone on the Internet costs no more (in fact, probably costs less) than does limiting access to a few research institutions. Of course, an article freely available on the web is not only free to people outside the university system but also to those who have traditionally had access via library subscriptions. Consequently, many librarians consider OA "the best candidate for solving the problem of high fees as a barrier to libraries' providing scholarly information to their users." ${ }^{29}$ They hope that OA will compete with the academic publishing monopolies and force them to reduce prices or abandon the subscription business model as economically unsustainable.

Although universal and free access to scholarly research is an admirable goal, current attempts to achieve OA are inadequate because they also fail to resolve the fundamental dilemma of collective action faced by the academic community. So far, both Green OA and Gold OA - the primary methods of achieving OA goals that advocates have promoted - rely primarily on local decisions made by individual institutions and authors to succeed. As long as they do so, OA is unlikely to become a comprehensive alternative to subscription publishing. Every librarian and scholar may clearly see that an OA system is preferable to the current system and may even see how their own actions could contribute to creating it but still fail to successfully coordinate their efforts to achieve it.

Green OA asks authors to self-archive their research. After (or before) her work has been accepted for publication, the author posts a copy of the article on another website where it is archived and made available to everyone on the web. Libraries have supported Green OA primarily by hosting Institutional Repositories (IRs) where authors at their campus can archive their publications. The costs of setting up and managing an IR often are justified by goals that make sense from the perspective of the local institution. By gathering together all of the research performed by different departments of a university, an IR can showcase the research productivity of the institution. An IR also can be a useful tool for archiving digital outputs unrelated to peer-reviewed publications such as press releases, campus periodicals, and architectural plans. ${ }^{30}$ IRs are popular with many librarians as a new way of adding value to their institutions while contributing to the broader goals of the OA movement by making scholarship available to users outside the university.

Nevertheless, it is unlikely that Green OA will become a comprehensive alternative to journal subscriptions because it relies on publishers to manage peer review and editing for most of its content. It is not surprising that libraries would take this approach because it still does not make sense for a university to publish specialized journals of interest only to a small minority on campus. In a few cases, library IRs host new OA journals edited by campus faculty, but there is no plan for somehow distributing responsibility for editing the 25,000 or so academic journals currently being published to academic libraries, and it is not clear who would do that work if were no longer profitable for subscription-based publishers to do it. According to one observer, "Green OA is like ouroboros, the snake that eats its own tail. It works best when it is less than perfect; when it is perfect it undermines the economics of the original publication." ${ }^{31}$ If too many libraries were to cancel a journal's subscriptions due to the availability of its articles in repositories, it is possible that the publisher would discontinue the journal 
so that no one would have access to its future articles, either through a subscription or in a repository.

Consequently, many OA advocates consider Green OA a "supplement" to subscription publishing rather than an alternative to it, arguing that Gold OA ultimately will become the true alternative. Gold OA refers to peer-reviewed journals that make all of their content immediately and freely available on the web without subscription. Gold OA publishers use various methods to pay their costs. Some gold OA journals are supported by the membership fees of a scholarly society. Some are supported by philanthropy or by university funds. Others rely on authors to pay the cost of publishing their articles through Article Processing Fees (APCs). A recent study estimates that approximately 20 percent of the peer-reviewed articles published in 2014 were in Gold OA journals. Approximately 33 percent of the OA journals and 64 percent of the OA articles published in 2014 relied on author payments to cover their costs. ${ }^{32}$

Since the release of the Budapest Open Access Initiative in 2002, which is often seen as the origin of the OA movement, the number of Gold OA journals has steadily increased, but they have had little effect on subscription costs for academic libraries so far. Because the scope of Gold OA content is not comprehensive enough for libraries to confidently cancel subscriptions to established journals, subscription prices have continued to increase at a rate higher than the rate of inflation, and it is an open question whether Gold OA will break the monopolistic hold over the most prestigious content held by subscription publishers. The most influential argument favoring the ultimate success of Gold OA publishing is David Lewis's 2012 article on "The Inevitability of Open Access" in College $\mathcal{E}$ Research Libraries. Lewis predicts that 90 percent of scholarly peer-reviewed articles will be published in OA journals by 2020 or $2025 .^{33}$ Lewis's argument is worth considering in detail because he explicitly articulates the implicit assumptions of many who believe that Gold OA ultimately will relieve libraries of the burden of high-priced subscriptions.

Lewis asserts that Gold OA is "disruptive innovation" as defined by the business theorist Clayton Christensen. Christensen's theory, which has become popular with Silicon Valley entrepreneurs seeking to enter new markets, posits that certain types of technological change disrupt markets so that dominant companies are suddenly dislodged by upstart competitors better able to deploy the new technology. Christensen developed an S-shaped adoption curve for disruptive innovations that predicts that use of the new technology increases gradually at first; but, after penetrating a certain percentage of the market, disruptive innovations "take off" and rapidly dominate the entire industry. By applying Christensen's adoption curve to academic journal publishing, Lewis predicts that the modest and gradual increase that OA publishing has enjoyed during that last 15 years or so is but a prologue. Within the next decade, there will be a "radical shift in the nature of scholarly journal publishing" because OA will rapidly disrupt the business model of subscription publishers. ${ }^{34}$

Lewis acknowledges that using Christensen's curve to predict the future of scholarly publishing is a "bold claim," and there are good reasons to be skeptical of his predictions. ${ }^{35}$ Christensen initially developed his theory through a close historical analysis of the computer disc drive industry in the 1950s-1980s, and there is some doubt that Christensen's theory accurately explains what happened in that industry. ${ }^{36}$ As the New Yorker has shown, established businesses in the disc drive industry were much more successful in adapting to new technologies than Christensen acknowledged. ${ }^{37}$ Even if Christensen's innovation curve accurately describes the rate at which customers adopt new types of computer hardware, it is not clear that it is applicable to the complex world of academic publishing. OA is not a technological innovation in the same way that 5.25 or 3.5 disc drives were new technologies that replaced earlier versions of computer data 
storage. OA is a different business model or perhaps a different philosophical approach to academic publishing. Of course, e-journals themselves are a new technology that has rapidly replaced print journals, but both subscription-based and OA business models are compatible with the technology of e-journals, just as subscription-based and open access channels are compatible with the technology of cable television.

Regardless of the reliability of Lewis's use of Christensen's adoption curve to make predictions about the specific growth rate of OA publishing, his arguments about the fundamental advantages of OA as a business model for academic publishing articulate the assumptions of many OA advocates who make more modest claims about when Gold OA will succeed. Lewis argues that OA journals eventually will have a significant advantage over subscription-based journals in attracting the best papers and authors. Because academic authors "do not exchange their work for money," they don't benefit directly from subscription fees paid by readers. If everything else were equal, few academics would choose to hide their work behind a publisher's paywall instead of making it freely available to all interested readers. Lewis acknowledges that the majority of academic articles still appear in subscription journals because not everything else is equal yet. "Because it takes time for a journal to establish a reputation, today most high-prestige journals are subscription-based." ${ }^{38}$ As new Gold OA journals develop reputations for high-quality scholarship, however, Lewis argues that it will be harder and harder for subscription-based publishers to attract the best content into their walled gardens.

OA advocates have been making similar arguments about the inherent advantages of OA for academic researchers for several years, but there are good reasons to doubt that everything else will become equal anytime soon. In the academic environment, prestige and reputation have a lot of staying power. The list of the top 10-50 most prestigious universities in the United States in 1930 is remarkably similar to the list of the most prestigious universities today. So far, leading firms in the academic industry have been remarkably resistant to disruptive innovators. The marketplace for academic journals is larger and more fluid than the marketplace for academic institutions, but it is hard to see journals that have been leaders in their fields for years suddenly losing their edge.

Another difference between OA and subscription journals for authors is the potential financial costs to them. It is not clear how much authors would be willing to pay to enjoy the benefit of wider distribution of their research. IR managers have learned that few authors are willing to put much time and effort into depositing articles into repositories despite the benefit of increased access. Unless there is an institutional mandate or the repository managers do most of the work for the researchers, there is very little self-archiving in repositories. Researchers have limited motivation to make existing publications OA because they can be confident that most of their peers at research institutions will have access to their work through library subscriptions or through direct exchange between colleagues. Although wider distribution is desirable, it is not a high priority for busy academics because the key readers who determine the success of their careers have access to subscription content. If few authors are willing to voluntarily invest the time and effort required to obtain the benefits of OA through self-archiving in an IR, it is unlikely that many of them will voluntarily pay an APC to get their article in a Gold OA journal. ${ }^{39}$ In a 2015 survey of 2,020 academic authors at research institutions, MacKenzie Smith and Ivy Anderson determined that whether or not a journal was open access was a relatively insignificant consideration when authors were deciding where to publish. ${ }^{40}$

One response to this objection is to argue that the costs of OA publication do not have to be passed on to authors. If OA publishing is more efficient than subscriptionbased publishing and if libraries no longer have to pay for subscriptions, libraries easily 
could provide financial support for an OA publication system without forcing authors to pay new fees. Lewis demonstrates that there is plenty of money in the academic publishing marketplace to pay for Gold OA publishing:

In 2008-2009, the 122 members of the Association of Research Libraries spent $\$ 881,547,511$ on current serials. Mark Ware and Michael Mage estimate that annual revenues generated from English-language STM journal publishing to be $\$ 8$ billion in 2008, up 6 to 7 percent from 2007. Universities paid much of this. If some of this money could be redirected into more cost-effective ways of distributing scholarship, such as institutional subsidies for open access publishing ventures or author charges to open access journals, this would be a benefit. ${ }^{41}$

However, Lewis's hope that some of the billions of dollars that academic libraries spend on subscriptions "could be redirected" toward OA publishing will be difficult to achieve because of the dilemma of collective action. Although it is likely that university libraries could develop a more efficient system of scholarly communication if they were to redeploy their collective subscription budgets, each individual librarywhen it decides how to spend its own little piece of that huge pie-has little incentive to redirect its own expenditures. If a university library redirects spending away from subscriptions toward subsidizing APCs and OA journals, it is making a decision that benefits the broader scholarly community at the expense of local researchers who will have reduced access to scholarly content. That is a difficult choice to make when librarians are evaluated by their local users rather than the academic community as a whole. It is much easier for a librarian to buy access to whatever content she can afford with her limited budget and wait until OA becomes pervasive before shifting subscription funds to support OA, especially if the librarian believes that the expansion of OA will be as quick and inevitable as Lewis predicts. Unfortunately, if every librarian waits for every other librarian to make the investments necessary to develop a sustainable system of Gold OA publishing, it may never happen.

The underlying contradiction in Lewis's analysis is that he combines an expectation that "inevitable" laws of market competition and technological change will produce a pervasive system of OA publishing with the hope that academic librarians will make decisions that violate their private, market-based incentives to fund the new system. As Olson argued, the mere fact that a collective good would benefit everyone involved does not mean that they will voluntarily act to achieve their shared interest. ${ }^{42}$ Many of the OA advocates who believe that Gold OA is a more rational and beneficial method of communicating between scholars similarly fail to address this dilemma.

\section{Mandates}

The growing interest in OA mandates demonstrates an increasing awareness that the OA movement cannot rely on private decisions made by individual researchers to achieve its goals. According to the Registry of Open Access Repository Mandates and Policies (ROARMAP), there were 769 OA mandates or policies (130 in the United States) as of January 2016. ${ }^{43}$ Most mandates have been implemented by universities or other institutions engaged in research. Government agencies that fund research also have begun to mandate that authors make research supported by their grants freely available to the public. Since 2008, the National Institutes of Health in the United States has required that research funded by their grants be freely available to the public within 12 months of initial publication. In 2016, the U.S. Congress is considering the Fair Access to Science and Technology Research (FASTR) Act, which would impose a similar mandate on research supported by any federal grant. ${ }^{44}$ Academic publishers have lob- 
bied against funder mandates because it seems likely that they will improve libraries' ability to negotiate with publishers. Knowing that much of the medical and technical research supported by the government will be freely available within 12 months of its initial publication reduces the value of journal subscriptions for many libraries. Nevertheless, mandates have not had a significant impact on journal prices so far, and it is not clear how much effect more extensive mandates such as FASTR would have.

Steven Harnad, an early and committed advocate of OA, makes an ambitious argument for the ultimate effectiveness of OA mandates. ${ }^{45}$ Although Harnad is disappointed that academics have demonstrated little interest in self-archiving "despite all of the benefits," he acknowledges that few of them will make the effort to do so without external motivation. Thus, Harnad argues that developing a comprehensive OA publishing system to replace subscription publishing will require mandates that are "convergent and collaborative rather than divergent and competitive." For OA to succeed, the vast majority of research institutions will have to have simultaneous OA mandates that require immediate deposit in a repository as soon as an article is published. After implementing a comprehensive system of mandates, libraries will be able to cancel their journal subscriptions safely, knowing that few academic articles will ever be locked behind paywalls again. Publishers will be forced to adapt to the new economic reality by downsizing their operations, eliminating unnecessary activities, and limiting themselves to managing the peer review process funded by relatively low-cost APCs.

Unlike Lewis, Harnad perceives that addressing the serials pricing crisis will require collective action. The logic of his proposal is similar to the logic behind "closed shop" union organizing. Just as unions believe that most workers will be better off if they do not have the freedom to choose whether they will become members, Harnad argues that academics will be better off collectively if individual researchers don't have the freedom to decide for themselves whether to use OA or not. Just as the collective power of the union allows it to negotiate better deals for workers, the collective power of academic institutions enforced by universal mandates will allow universities to dictate terms to publishers.

Many of those who are involved in the OA movement consider Harnad's vision utopian, and there are a couple of problems that make Harnad's strategy untenable. The first is that many OA mandates are relatively loose and permissive. A majority of university OA mandates in the ROARMAP database "request" rather than "require" OA. Often, university OA policies are general statements in support of OA principles that don't require researchers at an institution to change their behavior in any specific way. Even mandates that require OA usually allow exceptions for authors who request them and allow for embargoes, which put the article behind a paywall for the first 12 months or so after it has been published. Funder-based mandates usually require OA, but they also tend to allow embargoes that would require researchers who want to keep up to date with the latest results to maintain journal subscriptions. It could take a long time for this collection of loose OA policies to coalesce into a universal OA mandate that would give libraries confidence in cancelling journal subscriptions.

The second problem with Harnad's strategy is that a successful and universal OA requirement imposed by academic institutions would essentially become an "unfunded mandate" for publishers. Harnad believes that publishers would adapt to their new economic constraints by transforming their business practices, but another possibility is that they would stop publishing academic journals if it were no longer profitable for them to do so. As of 2010, Harnad estimates that 2.5 million peer-reviewed articles are published each year in 25,000 academic journals. If every academic library were to cancel all of its subscriptions tomorrow, and publishers were to respond to the loss of income by ceasing to publish their journals, would anyone else be prepared to 
make sure that all of those articles are reviewed and published or would the scope of academic publishing drastically contract? The dilemma for libraries is that publishers really do solve a collective action problem by distributing the costs of publishing highly specialized journals across the academic community as a whole. In the digital economy, providing this service has given them the power to charge excess prices. But if libraries simply refuse to pay those fees and publishers go on strike, there is no comprehensive plan for libraries and universities to take over the tasks that were previously outsourced to publishers.

\section{Alternative Strategies}

My analysis suggests that libraries probably are doomed to pay too much for journal access for the foreseeable future. The challenges of collective action are daunting, and the excess costs of the current system are bearable for the university system as a whole. Despite absorbing an increasing percentage of library budgets, journal subscription fees still are a relatively insignificant cost within most university budgets. For any single library, the pragmatic strategy is to focus on negotiating better deals with publishers, recognizing that there is a large range of flexibility between the highest price the library would be willing to pay and the lowest price that a publisher would be willing to accept. ${ }^{46}$ By joining together in consortia, individual libraries can increase their leverage and negotiating power. Furthermore, the mere possibility of an Open Access system of scholarly communication, even if it never comes to fruition, gives libraries some leverage in their negotiations with publishers. Publishers know that there are potential alternatives if they increase prices to the breaking point where universities decide that the costs are no longer sustainable, although it is hard to know where that breaking point would be after decades of consistent price increases.

Nevertheless, my analysis also suggests that a cooperative strategy adopted by university libraries fully cognizant of the challenges of collective action could lead to a more efficient system of scholarly communication that better aligns with the values of the academic community for whom knowledge is a community good that ought to be shared rather than a commodity that ought to be sold to the highest bidder. Harnad is right to argue that a "convergent and collaborative rather than [a] divergent and competitive" approach is necessary to achieve his vision, but our collaborative efforts have to go beyond simply refusing to participate in the current system of subscription publishing. They also have go beyond the emphasis on OA as a specific end goal and focus more on the political strategies required to overcome the real and pervasive problems of collective action faced by university libraries scattered around the world when confronting a small group of well-funded, highly organized commercial publishers. To meet this challenge, librarians need to develop a comprehensive strategy for collectively funding the costs of managing scholarly communication on a global scale.

My analogy between the dilemmas faced by 21st-century librarians and 19th-century farmers suggests that some of the political strategies employed during the Progressive Era of the late 19th and early 20th century to address monopoly power would be appropriate. One obvious way of attempting to force monopolistic corporations to serve the public good used frequently in the early 20th-century United States is to regulate and control their prices. Industries that require large initial investments, benefit from network effects, and enjoy economies of scale such as railroads, cable television providers, and utilities often are considered natural monopolies because they are unlikely to face effective competition in the marketplace. Because it would be wasteful to build the redundant infrastructure required to force market competition on them, the government can try to limit a natural monopoly's ability to exploit its customers by regulating its prices instead. 
Because journal publishers enjoy a government-created monopoly over the content of their journals based on copyright law and because digital publishing enjoys economies of scale that has allowed a small number of publishers to centralize control of many of the top titles in several fields, the dominant journal publishers could be considered natural monopolies whose prices have to be regulated for the common good. Instead of (or in addition to) asking the government to promote OA as an alternative to subscription publishing, libraries could ask legislators to impose a transparent system of tiered pricing on the big five journal publishers based on publicly accessible information about research institutions such as their number of students and their research output. As with the current system of "big deal" journal packages, large research institutions would subsidize smaller institutions by paying more for access to the same journals, but a transparent system of publicly posted prices would reduce the negotiation costs incurred by both libraries and publishers. In fact, because there is evidence that it is becoming increasingly difficult for libraries and publishers to negotiate mutually agreeable big deal contracts, this may be an excellent time to try to implement transparent price rates that would increase budget predictability both for libraries and publishers. ${ }^{47}$

In addition to offering libraries pricing transparency and cost relief, treating the big publishers as regulated monopolies can achieve the goals of the OA movement if the fees paid by each university to the publishers were to become access fees for institutional authors rather than access fees for institutional readers. While the content in the journals would be freely available to all readers everywhere, the annual access fee that an institution pays to a publisher would give its researchers the right to publish in their journals. To encourage institutional subscriptions, high APCs could be charged to authors at research institutions that choose not to subscribe, whereas unaffiliated authors would publish for free. The benefit of this strategy is that it would take advantage of the current digital infrastructure that the large publishers already have built in order to achieve OA goals. It also addresses a free rider problem faced by the OA movement, which is how to provide access to those unaffiliated with academic institutions without allowing rich institutions, whose investment is necessary to support the system, to ride for free. By tying institutional costs to something else that institutions value-author access to prestigious journals - this approach better aligns institutional incentives with OA goals.

Of course, possible objections to governmental regulation immediately suggest themselves. Currently, the dominant political ideology in Western capitalist countries, especially in the United States, is hostile to regulation, and it would be difficult to convince politicians to impose prices on an industry that hasn't been regulated in the past. Moreover, even if some kind of International Publishing Committee were created to establish price rates, there is a chance that regulators would be captured by publisher interests. Such a committee might be less inclined to defend the needs of thousands of academic institutions scattered around the world than the interests of a few large, well-organized, and well-funded academic publishers. Nevertheless, library organizations such as the American Library Association (ALA), the Association of Research Libraries (ARL), and the Scholarly Publishing and Academic Resources Coalition (SPARC) have had some success in lobbying legislatures on behalf of OA mandates for publicly funded research such as FASTR..$^{48}$ Why not use the collaborative power of such organizations to build public support for and to lobby the government for broader and more comprehensive legislative action to address the journal cost crisis faced by libraries? Despite the general skepticism toward governmental regulation in American politics, many American industries were regulated in response to popular protests during the Progressive and New Deal eras, and there is a popular perception 
that "information wants to be free" in the digital age that could be used to promote governmental action to make this desire a reality for scholarly articles. ${ }^{49}$

To bypass the possible complications of getting relief through governments, another possibility is for academic institutions to organize themselves to negotiate their own standardized pricing agreements with publishers. Just as workers can address their dilemma of collective action by forming unions to bargain with employers, universities could join together in a united coalition to negotiate nationwide or worldwide contracts with journal publishers. To some extent, universities already are collaborating in consortia to negotiate prices, but there are hundreds of library consortia in the United States negotiating separate contracts with publishers - often in secret. An international union of academic libraries could negotiate OA contracts with the publishers in which a transparent tiered pricing system would be tied to access for institutional authors.

As indicated in Olson's analysis of unions and closed shops, librarians would face collective action challenges in trying to organize an international union of libraries. There are many costs involved in forming and maintaining a union. Negotiators would have to be hired to bargain with the publishers. Agreements reached with the publishers would have to be monitored and enforced. Determining how the costs should be distributed to different institutions would be a challenge. There is no formula for deciding how much author access would be worth to different types of institutions, and differences of opinion would have to be negotiated and compromised. However, trying to solve these problems is a more viable strategy than merely encouraging individual authors to switch to OA publishing when they have limited private incentives to do so. Perhaps a philanthropic institution interested in increasing access to scholarly knowledge could make a strategic investment. Rather than investing in a few OA publications at the margins of scholarly communication, a philanthropic investment in an organization that would help academic libraries negotiate successfully with existing academic publishers could give the general public access to larger and more significant range of academic research.

A more ambitious solution would have libraries not simply regulate the publishers' pricing but actually take over the services provided by publishers. Currently, library publishing projects tend to be based within specific institutions and are engaged in relatively small endeavors that don't make much of a difference within the overall academic publishing environment. ${ }^{50}$ By working together instead of separately, libraries could pool together the large sums they currently spend on subscriptions simply to buy ScienceDirect and the Wiley journal platform and then run them as cooperatives. While it seems unlikely that private investors would want to sell such profitable enterprises at a reasonable price, the ability of libraries to collaborate might give them the leverage to make threats that could encourage the owners of Wiley and Elsevier to be reasonable in sales negotiations. If the publishers are unwilling to sell, another possibility would be for academic libraries to collectively build their own shared journal publishing platform. Editors of existing journals could be encouraged to move their titles to the new shared platform. A cooperative journal publishing enterprise run by academic libraries regardless of how it was created could again be an OA platform funded by a tiered pricing schedule in which institutions pay for author access rather than reader access.

Of course, the alternative strategies proposed here are preliminary sketches that would need to be fleshed out before they could be acted on, but they are offered as an invitation for academic librarians to think in more creative and comprehensive ways about the problem of "conscious coordination" in the management of the scholarly record. As long as universities stay focused on their local needs, it makes sense for them to outsource the responsibilities of managing, storing, and editing journals. However, as 
the scholarly community increasingly shares a collective collection, it makes more and more sense for the research institutions to take back those publishing responsibilities and manage them jointly. For academic libraries to continue to achieve their traditional role of storing, organizing, preserving, and providing access to the scholarly record, they increasingly will have to take responsibility for the entire cycle of scholarly communication from publishing and editing through preservation, but it is unlikely that they will succeed in doing so through the uncoordinated actions of individual institutions and will require new experiments in cooperation and coordination.

\section{Notes}

1. Paul N. Courant and Matthew Nielsen, "On the Cost of Keeping a Book," in The Idea of Order: Transforming Research Collections for 21st Century Scholarship (Washington, D.C.: Council on Library and Information Resources, 2010), 81-105.

2. Andrew M. Odlyzko, "Open Access, Library and Publisher Competition, and the Evolution of General Commerce," Evaluation Review 39, no. 1 (Feb. 2015): 130-63, doi:10.1177/0193841X13514751. See figure 5, "Fraction of library budgets devoted to all acquisitions and to purchases of serials," based on ARL statistics.

3. "Harvard University Says That It Can't Afford Journal Publishers' Prices," theguardian. com, last modified April 24, 2012, available online at www.theguardian.com/science/2012/apr/24/ harvard-university-journal-publishers-prices [accessed 16 December 2016]. Per the Association of Research Libraries (ARL), the Harvard Library budget in 2013-2014 was the largest in the ARL at $\$ 123,135,255$. See the Library Investment Index available from ARL Statistics, available online at http://www.arlstatistics.org/analytics [accessed 18 January 2016].

4. Brian Lavoie and Constance Malpas, Stewardship of the Evolving Scholarly Record: From the Invisible Hand to Conscious Coordination (Dublin, Ohio: OCLC Research, 2015), available online at www.oclc.org/research/publications/2015/oclcresearch-esr-stewardship-2015.html [accessed 16 December 2016].

5. I take the term "collective collection" from Lorcan Dempsey. See Lorcan Dempsey, Brian Lavoie, Constance Malpas, Lynn Silipigni Connaway, Roger C. Schonfeld, JD Shipengrover, and Gunter Waibel, Understanding the Collective Collection: Towards a System-wide Perspective on Library Print Collections (Dublin, Ohio: OCLC Research, 2013), available online at http://www.oclc.org/ research/publications/library/2013/2013-09r.html [accessed 16 December 2016]. The monograph focuses on print, but the systemwide perspective described may be more important for digital collections, which - from a technological perspective-are much easier to share than print.

6. Mancur Olson, The Logic of Collective Action: Public Goods and the Theory of Groups (Cambridge, Mass.: Harvard University Press, 1965), 2.

7. Much has been written about the problems of collective action by researchers in Economics, Political Science, and other fields since the 1960s. A good summary is Elinor Ostrom, "Coping with Tragedies of the Commons," Annual Review of Political Science 2 (1999): 493-535. The first chapter of Ostrom's Governing the Commons: The Evolution of Institutions for Collective Action (Cambridge, U.K.: Cambridge University Press, 1990) also has a good overview.

8. Olson, The Logic of Collective Action, 86.

9. The recent Affordable Care Act uses the same logic to try to reduce the cost of healthcare for American citizens. By using the power of the government to force everyone buy insurance whether they want to or not, it seeks to distribute and reduce the overall cost of insurance.

10. "Scanning Services: Digitizing Print Collections with the Internet Archive," Internet Archive, available online at https://archive.org/scanning [accessed 18 January 2016].

11. Courant and Nielsen, "On the Cost of Keeping a Book," 81-105.

12. The HathiTrust and JSTOR have come closest to achieving this vision for American academic libraries so far. In both cases, the collective online collections were built primarily through the efforts of external organizations outside of libraries. Most of the books in the HathiTrust were digitized by Google, a private corporation that didn't face the collective action dilemmas that the libraries would have had to overcome if they tried to do it for themselves. For an overview of HathiTrust, see Jeremy York, "This Library Never Forgets: Preservation, Cooperation, and the Making of the HathiTrust Digital Library," Archiving 2009 Final Program and Proceedings, available online at https://www.hathitrust.org/documents/This-Library-Never-Forgets.pdf [accessed 16 December 2016]. JSTOR, a nonprofit organization founded by the Andrew W. Mellon Foundation, has built a large collection of high-quality digitized journals. Although it is a nonprofit, JSTOR's 
relationship to libraries is similar to the relationship between journal vendors and libraries. It charges libraries for institutional access to the content available on its servers. See Roger Schonfeld, JSTOR: A History (Princeton, N.J.: Princeton University Press, 2003).

13. For a good recent account of the development of the railroad network in the United States, see Richard White, Railroaded: The Transcontinentals and the Making of Modern America (New York: Norton, 2011).

14. Conflict between railroads and farmers occurred frequently during the later decades of the 19th century. The Granger Movement of the 1870s, which sought to increase cooperation between farmers and to improve their economic situation, fought for increased regulation of the railroads. See Solon Justus Buck, The Granger Movement: A Study of Agricultural Organization and Its Political, Economic, and Social Manifestations, 1870-1880 (Cambridge, Mass.: Harvard University Press, 1913); Lee Benson, Merchants, Farmers \& Railroads: Railroad Regulation and New York Politics 1850-1887 (Cambridge, Mass.: Harvard University Press, 1955); or James Dabney McCabe, History of the Grange Movement; or, the Farmer's War against Monopolies: Being a Full and Authentic Account of the Struggles of the American Farmers against the Extortions of the Railroad Companies (Philadelphia: National Publishing Company, 1873). Frank Norris's famous novel The Octopus: A Story of California (New York: Doubleday, Page \& Co, 1901) is based on conflicts between wheat farmers and the Southern Pacific Railroad - often depicted as an octopus in political cartoons - in the 1880s. For a more recent account of the western railroads and the various antimonopoly groups that opposed them, see White's Railroaded, especially 109-18.

15. Recently, the economic challenges discussed in this study have led to increased interest in publishing among librarians. For a list, see the Library Publishing Coalition, Library Publishing Directory 2016, ed. Sarah K. Lippincott (Atlanta: Library Publishing Coalition, 2016), available online at www.librarypublishing.org/sites/librarypublishing.org/files/documents/Library_Publishing_Directory_2016.pdf [accessed 16 December 2016]. However, the advocates of library publishing understand that this is not a traditional responsibility that academic libraries have generally assumed in the past but a response to a "new paradigm in scholarly publishing." See "Background," Library Publishing Corporation, available online at www.librarypublishing.org/ about-us/background [accessed 31 January 2016].

16. Of course, managing access to electronic resources housed on publishers' servers is not costless for libraries. Librarians have to maintain proxy servers or some other system of authentication. They have to maintain coverage databases and OpenURL servers to direct library patrons to the appropriate copy of the article. They have to negotiate and manage license agreements and track usage to identify the highest value resources. But these costs are not a technological requirement of electronic journal management in the same way that organizing and tracking the volumes on the library shelves was a technological requirement of printed journals. The new tasks required for managing electronic resources are necessary primarily to protect the publishers' copyright and license agreements and actually inhibit the potential for widely sharing and distributing scholarship made possible by the new technology.

17. Angus Phillip, "Business Models in Journals Publishing," in The Future of the Academic Journal, ed. Bill Cope and Angus Phillips (Oxford, U.K.: Chandos Publishing, 2009 ), 87.

18. On the serials crisis in the 1990s, see Anne M. Pascarelli, "Coping Strategies for Libraries Facing the Serials Pricing Crisis," Serials Review 16, no. 1 (Spring 1990): 75-81; Emily R. Mobley, "Ruminations on the Sci-Tech Serials Crisis," Issues in Science and Technology Librarianship (Fall 1998), doi:10.5062/F4V69GKR; and Glenn S. McGuigan, "Publishing Perils in Academe: The Serials Crisis and the Economics of the Academic Journal Publishing Industry," Journal of Business \& Finance Librarianship 10, no. 1 (2004): 13-26.

19. Vincent Larivière, Stefanie Haustein, and Philippe Mongeon, “The Oligopoly of Academic Publishers in the Digital Era," PLOS ONE, June 10, 2015, doi:10.1371/journal.pone.0127502.

20. Roger Clarke, "The Cost Profiles of Alternative Approaches to Journal Publishing," First Monday 12, no. 12 (Dec. 3, 2007), available online at http://firstmonday.org/ojs/index.php/fm/ article/view/2048/1906 [accessed 16 December 2016].

21. For an overview of the strategies that companies use to maximize profits in a networked economy in which it is expensive to produce a the first copy of a digital object but costs almost nothing to distribute additional copies to consumers, see Carl Shapiro and Hal Varian, Information Rules: A Strategic Guide to the Network Economy (Boston: Harvard Business School Press, 1999).

22. Theodore C. Bergstrom, Paul N. Courant, R. Preston McAfee, and Michael A. Williams, "Evaluating Big Deal Journal Bundles," Proceedings of the National Academy of Sciences 111, no. 26 (May 2014), doi:10.1073/pnas.1403006111, 9426.

23. Odlyzko, "Open Access, Library and Publisher Competition," 132.

24. Richard Van Noorden, "The True Cost of Science Publishing," Nature 495 (Mar. 2013): $426-29$.

25. Odlyzko, “Open Access, Library and Publisher Competition," 149. 
26. Based on a survey of 2,020 academic authors at research institutions in 2015, MacKenzie Smith and Ivy Anderson argued that most of the scholars that they surveyed approve of "[open access] as readers and as a moral good, but most have access to what they need." Thus, Open Access is not a high priority for them. MacKenzie Smith and Ivy Anderson, "Investigating a Sustainable Model of Open Access Article Processing Charges for Large North American Research Institutions," Coalition of Networked Information (CNI) Fall Forum, December 14, 2015, Video and PowerPoint available at https://www.cni.org/topics/e-journals/is-gold-open-access-sustainableupdate-from-the-uc-pay-it-forward-project [accessed 16 December 2016]. See slides 13-14 of the PowerPoint on the "ambivalence" of academic authors regarding Open Access.

27. Odlyzko, "Open Access, Library and Publisher Competition," 148.

28. "Budapest Open Access Initiative," February 14, 2002, available online at www.budapestopenaccessinitiative.org/read [accessed 16 December 2016].

29. Sara L. Rizor and Robert P. Holley, "Open Access Goals Revisited: How Green and Gold Open Access Are Meeting (or Not) Their Original Goals," Journal of Scholarly Publishing 45, no. 4 (July 2014): 321-35, doi:10.3138/jsp.45.4.01.

30. Marisa Ramirez, "The DigitalCommons@CalPoly: A Case Study on the Development and Implementation of the Institutional Repository," Digital Commons @ Cal Poly (Oct. 2010), available online at http://digitalcommons.calpoly.edu/lib_fac/97 [accessed 16 December 2016].

31. Joseph Esposito, "When It Comes to Green OA, Nice Guys Finish Last," The Scholarly Kitchen (blog), September 26, 2013, available online at http://scholarlykitchen.sspnet.org/2013/09/26/ when-it-comes-to-green-oa-nice-guys-finish-last/ [accessed 16 December 2016].

32. Walt Crawford, "Idealism and Opportunism: A Gold OA Overview," ALA TechSource 51, no. 6 (2015), available online at https://journals.ala.org/ltr/article/view/5757/7209 [accessed 16 December 2016].

33. David W. Lewis, "The Inevitability of Open Access," College E Research Libraries 73, no. 5 (Sept. 2012): 493-506, doi:10.5860/crl-299. For the specific prediction on when 90 percent of journals will be Open Access, see 501.

34. Lewis, "The Inevitability of Open Access," 501.

35. Lewis, "The Inevitability of Open Access," 501.

36. Clayton Christensen, The Innovator's Dilemma: When New Technologies Cause Great Firms to Fail (Boston: Harvard Business School Press, 1997).

37. Jill Lepore, "The Disruption Machine: What the Gospel of Innovation Gets Wrong," The New Yorker, June 23, 2014, available online at www.newyorker.com/magazine/2014/06/23/thedisruption-machine [accessed 16 December 2016].

38. Lewis, "The Inevitability of Open Access," 494.

39. In addition to a simple reluctance to pay the costs, there may be a concern that paying someone to publish your work is a form of vanity publishing in which the publisher's decision to distribute the research is based more on the author's willingness to pay than on the quality of her scholarship. There has been some controversy in the library literature about the prevalence of "predatory publishers," who are in business to collect APCs rather than to publish quality work. Beall's list, created by Jeffrey Beall, a librarian at the University of Colorado (see: http:// scholarlyoa.com/publishers/) includes a list of journals that he considers predatory. However, a recent article by Beall that was highly critical of the OA movement in general has undermined his reputation for objectivity. See: Jeffrey Beall, "The Open-Access Movement Is Not Really about Open Access," tripleC: Communication, Capitalism E Critique. Open Access Journal for a Global Sustainable Information Society 11, no. 2 (2013): 589-97, available online at http://triplec.at/index. php/tripleC/article/view/525 [accessed 16 December 2016]. Many OA advocates now wonder if Beall's list is a propaganda tool against OA rather than a reliable analysis of publishers. See, for example, Wayne Bivens-Tatum's response to Beall, "Reactionary Rhetoric against Open Access Publishing," tripleC: Communication, Capitalism \& Critique: Open Access Journal for a Global Sustainable Information Society 12, no. 2 (2014), available online at www.triple-c.at/index.php/tripleC/ article/view/617 [accessed 16 December 2016]. Nevertheless, most librarians agree that there are at least a few publishers primarily interested in making a profit from academic authors eager to share their work, and an easy heuristic for busy authors who want to avoid them is to stick with well-established subscription publications.

40. Open Access was the least important factor (out of the 8 factors presented to them) when researchers were deciding where to publish an article. The following were more important: 1) Quality or Reputation of the Journal; 2) Fit with Scope of Journal; 3) Audience; 4) Impact Factor; 5) Likelihood of Acceptance; 6) Time from Submission to Publication; 7) Editor or Editorial Board. See Smith and Anderson, "Investigating a Sustainable Model of Open Access Article Processing Charges for Large North American Research Institutions," slide 15 of the PowerPoint.

Some librarians blame the tenure review process for the emphasis on the quality or reputation of the journal in the publication decision of academics and argue that altering tenure review 
standards would increase use of OA journals. Although it is likely that changing tenure review protocols would alter the incentives for less-established scholars, there are many reasons that academics prefer to publish in high-quality journals that go beyond the formal performance review process. Even well-established scholars with tenure know that their work is more likely to be read closely by more people in their target audience if it appears in the top journal in their field. Also, for readers, the reputation of a journal still helps as a method of filtering and identifying articles worth reading, especially if they are reading about something that goes beyond their specific area of expertise.

41. Lewis, "The Inevitability of Open Access," 498.

42. Olson, The Logic of Collective Action, 2.

43. "ROARMAP: Registry of Open Access Repository Mandates and Policies," available online at http://roarmap.eprints.org/ [accessed 30 January 2016].

44. For an overview of FASTR, see Scholarly Publishing and Academic Resources Coalition (SPARC), "FAQ for the Fair Access to Science and Technology Research Act (FASTR)," available online at www.sparc.arl.org/advocacy/national/fastr/faq [accessed 24 January 2016].

45. Steven Harnad, "Gold Open Access Publishing Must Not Be Allowed to Retard the Progress of Green Open Access Self-Archiving," Logos 21, no. 3 (2010): 86-93, doi:10.1163/095796511X559972.

46. On the large variation in the annual prices negotiated by similar universities for similar collections of journals, see Bergstrom et al., "Evaluating Big Deal Journal Bundles," 9429.

47. See Bergstrom et al, "Evaluating Big Deal Journal Bundles," 9429, on the increasing failure of publishers and libraries to negotiate mutually acceptable license agreements. Previously, big deal prices were largely based on how much a library had paid for print subscriptions in the past. Now that this standard has become dated, it is getting harder for publishers and libraries to agree on a "fair" price for electronic journal packages.

48. ALA, ARL, and SPARC all have taken a public political stance in favor of FASTR. See ALA, "The Fair Access to Science and Technology Research Act (FASTR)," available online at www. ala.org/advocacy/advleg/federallegislation/access/fastr [accessed 24 January 2016]; ARL, "FASTR Bill to Enhance Public Access to Research Approved by US Senate Committee, available online at www.arl.org/news/community-updates/3701-fastr-bill-to-enhance-public-access-to-researchapproved-by-us-senate-committee [accessed 24 January 2016]; and SPARC, "FAQ for the Fair Access to Science and Technology Research Act (FASTR)," available online at www.sparc.arl.org/ advocacy/national/fastr/faq [accessed 24 January 2016].

49. The literature on Progressive Era regulation is vast. A good introduction is Steven J. Diner, A Very Different Age: Americans of the Progressive Era (New York: Hill and Wang, 1998). On the willingness of many to advocate for governmental action in favor of their vision of free and fair distribution of information on the Internet, note the recent protests regarding Net Neutrality. For example, Ashley Killough, "Net Neutrality Protesters Sing, Chant at FCC chairman's Home," CNN, last modified November 11, 2014, available online at www.cnn.com/2014/11/11/politics/ fcc-chairman-protesters/ [accessed 16 December 2016].

50. Note the emphasis on institution-specific activities in the Directory of Library Publishing 2016, which is organized as a list of isolated universities and their local library publishing activities largely through Institutional Repositories. Also, note the limited investment of university resources in these projects. For example, Brigham Young employs 1.75 out of 171 FTE library staff in publishing; Cornell employs 7.5 out of 391 library FTE in publishing. For ARL libraries, FTE counts are available in the ARL statistics. 